attainable. It appears from all these results that the earth is being bombarded by streams of positrons and electrons of very great energy. These appear to come continually from outside our galactic system, but from where, or how they are produced, no one knows. The study of the passage of these rays through the atmosphere has led to the discovery of exciting new phenomena. The positron, first detected by Anderson in a cloud photograph, is now known to be one of the main constituents of the rays ; and this now member of the group of fundamental par. ticles has very great theoretical interest, since its experimental detection has shown the validity of Dirac's theory of 'holes'. Very great interest is attached to the behaviour of the very fast cosmic ray particles while passing through matter. The curious and striking phenomenon of the 'showers' still awaits explanation. It is clear that one is here in a region of physics where quite new types of phenomena occur.

\section{Humour and Humanism in Chemistry}

UNDER this title, Prof. John Read, of the University of St. Andrews, gave an address to the Alchemists' Club of the University of Glasgow on February 28. One of the chief defects in the average science course or textbook, he said, is the neglect of the human element. He deprecated this omission, which he holds responsible for many of the misconceptions of men of science by their colleagues of arts and letters, "who, from attending a limited number of strictly formal and impersonal lectures on science have often deduced that the man of science is of necessity cold, formal and aloof; narrow in outlook; insensible to the finer human emotions; incapable of expressing himself in the common tongue; devoid of humour and humanism; and a stranger to the humanities." In the course of a picturesque survey of selected aspects of historical chemistry, Prof. Read claimed that the study of chemistry, if approached befittingly, may reasonably take rank beside the socalled 'humanities', as a broadly educative, cultural, and humanising influence. He re-defined humour in various terms as the golden thread running through the whole history of chemistry : the real philosopher's stone-the universal catalyst. The present generation of chemists, he remarked, are inclined to take themselves too seriously; like Liebig, Wöhler, and their more remote alchemical forebears, they should include a large pinch of humour and humanism in their curricula. The narrowness of outlook which is becoming increasingly associated with the ultraspecialistic trend of contemporary chemical research can be combated most effectively by the cultivation of an interest in the broader humanistic aspects of chemistry. Those chemists who aspire to become leaders in the future should cultivate a discerning and sympathetic acquaintance with the past. During the ensuing discussion, in reply to Prof. T. S. Patterson, the speaker threw some new light upon the possible origin and interpretation of the enigmatical seventeenth century illustrations appearing in the Mutus Liber.

\section{4-in. Telescope for the University of Toronto}

THE issues of Engineering for March 9 and 30 and April 20 contain a fully illustrated description of the 74-in. reflecting telescope now being completed by Messrs. Sir Howard Grubb, Parsons and Co., at Newcastle for the David Dunlap observatory of the University of Toronto. An account of the instrument was published in Nature of October 14, 1933. The observatory, which is being given as a memorial to the late David A. Dunlap, of Toronto, by his widow and son, is being erected on Richmond Hill, $800 \mathrm{ft}$. above sea-level, a few miles north of Toronto. The circular steel building and the 61-ft. dome for housing the telescope were made by Messrs. The Cleveland Bridge and Engineering Co., Ltd., at Darlington, and these together with the main parts of the telescope were sent to Canada last year. The polishing of the mirror is now in hand. The telescope, the largest in the British Empire and the second largest in the world, weighs about 50 tons, of which the moving parts account for about 35 tons. The polar axis is $22 \mathrm{ft}$. long and the declination axis $13 \mathrm{ft}$. long; the driving wheel on the former having a pitch diameter of $8 \mathrm{ft}$. with 960 teeth of $8 \mathrm{~mm}$. pitch. The article gives details of the driving and controlling mechanisms. The disc for the mirror, of special Pyrex glass, was made by the Corning Glass Works, New York, and when received at Newcastle weighed 2 tons 6 cwt. For grinding and polishing the mirror a special machine has been made which allows the mirror to be tilted for testing purposes without being removed from the machine. The telescope, it may be added, may be used either as a Cassegrain or a Newtonian, for which two mirrors 19 in. and 20 in. in diameter respectively are provided.

The David Dunlap Memorial telescope is illustrated in the issue of the Sphere dated April 21, which also ineludes photographs of the new 36-in. Yapp reflector at the Royal Observatory, Greenwich. Accompanying these illustrations is an article entitled "Studying the Sun in Calcium Light" and several lunar photographs taken with the 100 -in. reffector at Mount Wilson, California.

\section{Scientific Publication and Bibliography}

AN ambitious plan for scientific bibliography and publications is described in a memorandum issued by Science Service, Washington. The plan is designed to eliminate some of the defects in our present system, such as the difficulty of publishing research results promptly or completely owing to the financial burden, and the inadequacy of much bibliographic work owing to lack of access to original papers, etc. It is proposed accordingly to centralise all scientific publication, abstracting and similar bibliographic services, and to substitute a photographic type of duplication for printed reproduction of scientific papers or abstracts. Under this scheme a research report, for example, submitted and accepted for publication, would be reproduced from the standard typescript form by some suitable method other than printing, and full copies of the 
report or paper would only be supplied to order. The author would, however, also provide a summary abstract, say, two hundred words in length, which after editing, if required, would be reproduced by the most suitable means and the abstract would be included in a weekly or monthly journal issued to all scientific workers desiring information in that particular field.

Thrs scheme does not discuss the fundamental difficulty of overlapping, but obviously presupposes that one abstract could serve the needs of several related branches of science or industry. It also proposes to deal with the difficulty of indexing scientific literature by assembling all the necessary subject cards for each published article or report and using an adequate numerical classification together with mechanical finding and sorting devices, thus affording a comprehensive basis for bibliographic work. The scheme visualises a public utility associa. tion for the United States of America which could afterwards be developed on international lines. Despite the inherent difficulties in the project, and the fact that the international aspects are among the most important and difficult in the problem of dealing efficiently with scientific literature, it should not be lightly dismissed. Bold treatment on such novel lines may possibly lead to a rational solution of a problem which has so often been attacked half. heartedly.

\section{Bureau of American Ethnology, 193I}

IN the forty-eighth annual report of the Bureau of American Ethnology for the year ending June 30, 1931, Mr. M. W. Stirling, chief of the Bureau, in making his usual report on the activities of his staff in the period under review, directs attention to archæological investigations carried out by him in Florida. Among the sites examined on the west coast was a large sand burial mound on Blue Hill Island, south of Key Marco, which was found to be of early post-Columbian Calusa origin. A number of structural features unusual in Floridan sand mounds was disclosed. Among them was a clay floor, six feet above the bottom of the mound, which gave evidence of having been the base of a temple structure. It was surrounded by post holes, in some of which the decayed remains of the wooden uprights were still in place. The "accompanying paper" of the report, which as usual takes up the greater part of the volume, does not on this occasion deal with researches in American ethnology carried out by members of the staff, but is a useful general index of the contents of the annual reports of the Bureau from their inception to date. It has been compiled by Dr. Biren Bonnerjea. Originally intended by Dr. Bonnerjea for his own use, the index has been adopted officially and published by the Bureau. As the early volumes cover the period in the 'eighties of the final resistance of the Indians to white control in the south-western States, they record much valuable material relating to the final stage of independent culture which the index will assist in preserving from oblivion.

\section{Modern Street Lighting}

THE characteristic and peculiar colours of the discharge lamps used for street lighting have at. tracted much interest to this important public service. With the development and research depart. ments of great companies behind it, this branch of lighting has made rapid progress. In a paper read to the Royal Society of Arts by J. M. Waldram on January 17, it was pointed out that the use of these lamps has led to material improvements in our knowledge, leading to a new technique. One of the immediate problems of street lighting is connected with the question of who is to pay for it. It is an anomaly that a national trunk road should be built, drained and maintained at the national expense, and the lighting left to local authorities, each lighting its section according to its own ideas and naturally being sometimes very limited as to the cost. The requirements of the motorist are the most difficult to satisfy. He has when moving at high speed to see every obstruction in the road many feet in advance, whatever the condition of the road surface. Claims have been made that certain lights have more fog-penetrating power than others, but recent experiments throw doubt on this. Experience shows that from the safety point of view, when driving, the spectral colour of the light matters little. In general, recent progress has been made mainly in the direction of lowering the cost of production of the light and thus making more light available, and in distributing it over the road in such a way that it is more helpful to both pedestrians and motorists.

\section{Short-Circuit Testing Station}

WHEN an electric generator is accidentally shortcircuited, huge currents are developed and unless the 'circuit-breakers' act promptly, serious damage may be done to the generator and there is a risk of fire. Until a few years ago, practical experience was the only guide to the rating of these circuit-breakers. The enormous currents required for testing purposes, in most cases, made the testing costs prohibitive. Proposals were made for a co-operative or national testing plant, but nothing materialised. In 1929 a private company, Messrs. A. Reyrolle and Co., Ltd., of Hebburn-on-Tyne, laid down their own testing station, which has proved capable of testing the largest circuit-breakers used in Great Britain. They have erected a miniature power station which has a capacity of 1.5 million kilovolt-amperes. Any short-circuit conditions which might possibly occur in practice can be produced in their testing room. The generators are driven by 5,500 volt motors connected with the public supply mains. Very large transformers are used to produce the heavy currents required. The observation gallery is built of reinforced concrete and has slits in the wall fronting the test bay, through which the behaviour of the apparatus under test can be safely observed. A system of traffic signal lights and alarm bells is installed outside the test bay to give warning when a test is about to be made and when all is clear. Shortcircuit phenomena can be observed in time intervals 